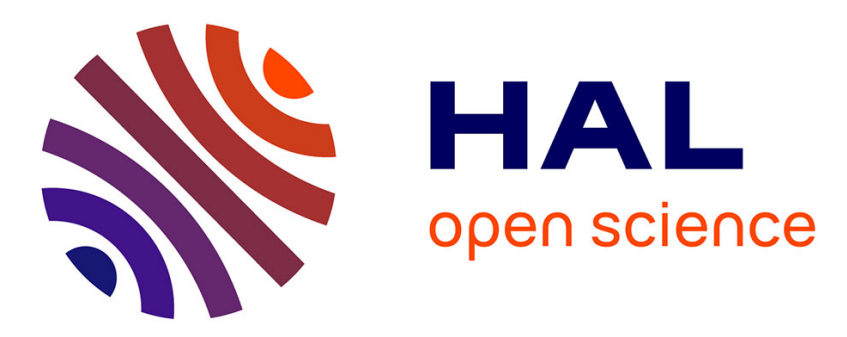

\title{
Ependymoma of the spinal cord in children. A retrospective french study
}

Alexandru Szathmari, Michel Zerah, Matthieu Vinchon, Christelle Dufour, Edouard Gimbert, F. Di Rocco, S. Chabaud, C. Conter, C. Mottolese, D. Frappaz

\section{To cite this version:}

Alexandru Szathmari, Michel Zerah, Matthieu Vinchon, Christelle Dufour, Edouard Gimbert, et al.. Ependymoma of the spinal cord in children. A retrospective french study. World Neurosurgery, 2019,

World neurosurgery, 126, pp.e1035-e1041. 10.1016/j.wneu.2019.03.033 . hal-03405359

\section{HAL Id: hal-03405359 \\ https://hal.univ-lille.fr/hal-03405359}

Submitted on 20 Dec 2021

HAL is a multi-disciplinary open access archive for the deposit and dissemination of scientific research documents, whether they are published or not. The documents may come from teaching and research institutions in France or abroad, or from public or private research centers.
L'archive ouverte pluridisciplinaire HAL, est destinée au dépôt et à la diffusion de documents scientifiques de niveau recherche, publiés ou non, émanant des établissements d'enseignement et de recherche français ou étrangers, des laboratoires publics ou privés.

\section{(c) (1) $\$$}

Distributed under a Creative Commons Attribution - NonCommercial| 4.0 International 
Version of Record: https:/www.sciencedirect.com/science/article/pii/S187887501930659X

Manuscript_952c7447d2dc107660a6839a42d231eb

Ependymoma of the spinal cord in children. A Retrospective French study.

Authors: Alexandru Szathmari ${ }^{1}$, M. Zerah², M. Vinchon ${ }^{3}$, C. Dufour ${ }^{4}$, E. Gimbert ${ }^{5}$, F. Di Rocco ${ }^{1}$, S. Chabaud ${ }^{6}$, C.

Conter $^{7}$, C. Mottolese ${ }^{1}$, D. Frappaz ${ }^{7}$

Affiliations

1. Department of Pediatric Neurosurgery. Hôpital Femme Mère Enfant. Hospices Civils de Lyon. Claude Bernard Lyon 1 University.

2. Department of Pediatric Neurosurgery, Hôpital Necker Enfants Malades, Paris. Université Paris Descartes.

3. Department of Pediatric Neurosurgery, Centre Hospitalier Roger Salengro, Lille.

4. Department Child and Adolescent Cancer. Institut Gustave Roussy, Villejuif.

5. Department of Pediatric Neurosurgery, Centre Hospitalier Pellegrin, Bordeaux.

6. Directorate of Clinical Research and Innovation (DRCI). Centre Leon Bérard and Hospices Civils de Lyon

7. Institut d’Hématologie Oncologie Pédiatrique (IHOPe), Centre Leon Bérard and Hospices Civils de Lyon.

\section{ABSTRACT}

Background: Ependymoma is the most frequent spinal tumor in adults but it is rather uncommon in children. The aim of this study is to summarize retrospectively clinical and therapeutic experience in the treatment of pediatric spinal ependymomas in France.

Material and methods: In this retrospective multicenter study, data from patients younger than 18 years old treated between 2000 and 2010 for spinal ependymomas were collected. Epidemiologic, tumor- and treatment-related data were analysed. Prognostic factors for progression free survival (PFS) were assessed. Results: Twenty-eight patients (22M, 6F) were identified. Median age at surgery was 13.67 (0.7 to 17.6 years). Initial gross total removal was achieved in 22 children and subtotal removal in 6 . Histologically, 15 were myxopapillary ependymomas, 11 grade II and 2 grade III ependymomas. Adjuvant initial radiotherapy (RT) was performed in 6 patients. Median follow-up was of 40 months ( 2.3 to 127.5 months). The 5-year PFS is $51 \%$ (IC95\% $=26.3 ; 71.2$ ) and the overall survival (OS) is of $100 \%$. In univariate analysis, only the gross total removal (GTR) had significant influence on the PFS ( $p=0.0013)$. A subgroup analysis showed a benefit of RT delivered to patients with GTR but it failed to prevent relapse in the group with initial subtotal removal (STR). 
Conclusion: Our data suggest that initial adjuvant radiotherapy may improve the PFS after GTR but does not prevent relapse in patients with STR. Further studies should aim to define more specific treatments in the latter group.

Key words: ependymoma in children, spine surgery, radiation therapy Introduction

Primary spinal cord ependymomas (SpEp) are rare in children. They account for less than $13 \%$ of all CNS ependymomas in the group between 0-19 years of age $\mathrm{e}^{1}$. Population based registries show an incidence rate as low as 0.06 per 100.000 people per year in US with predominance in male gender and in non-Hispanic whites $^{2}$. Age at diagnosis usually lies between 10 and 14 years. Histologically, spinal ependymomas comprise grade I myxopapillary ependymomas (MPE) that predominantly affect the conus-cauda equina region and WHO grade II/III tumours that may be found at any level of the central nervous system ${ }^{3}$.

There is no current prospective trial for the management of children with primary spinal ependymoma. The current SIOP ependymoma II study includes these patients in a registry and may provide useful information in the future. Meanwhile, better understanding of such an entity is necessary in order to improve the management of SpEp. The aim of this study is to summarize the retrospective clinical and therapeutic experience of children with a spinal ependymoma in France.

\section{Methods}

Between 2000 and 2010 medical records of patients younger than 18 years old with a primary SpEp treated in one of the following French Pediatric Neurosurgery and Oncology institutions (Institute Gustave Roussy Villejuif, Paris-Necker, Lille, Lyon, Bordeaux) were analysed. Epidemiologic (gender, age, potential predisposing status and symptoms at diagnosis, delay from initial signs to diagnosis), tumor- and treatmentrelated data (site and extension of the tumor, histology, extent of initial resection and number of relapse and complementary treatments) were retrospectively analysed. Two patients with cervical location were excluded as study focused on the most frequent location of spinal ependymomas of the child, thus at the distal part of the spinal cord. Most recent data were obtained from the follow-up files of the participating centers according to the French Data Protection Authority (CNIL 2211717 v 0). 
Progression-free survival (PFS) was calculated from the date of surgery to the date of recurrence/progression for patients who relapsed/progressed or until the date of latest news otherwise (censored data). The PFS was estimated using the Kaplan-Meier method. A Cox proportional hazard regression model was used to identify prognostic factors that can influence recurrence/progression such as gender, age at surgery, level of lesion(s), histological grade (I, II or III), quality of initial surgical removal (gross total removal GTR versus subtotal removal STR) and whether adjuvant RT was administered or not. Due to the small sample size, only univariate analysis was considered. A subgroup analysis according on removal status with or without RT was performed.

Results

Twenty-eight patients were identified. The main clinical characteristics are reported in Table 1. The median age at diagnosis was 13.67 year ( 7 month to 17.6 years). Sex ratio M:F was of 3.6:1. The median time interval between symptoms and diagnosis was 4 months ( 6 days to 3 years). Back pain was present in 26 of 27 evaluable patients $(92.5 \%)$ and another patient had no symptoms as the diagnosis of spinal ependymoma was made during systematic screening for NF2 disease. In the youngest patient, diagnosis was made at postnatal ultrasound for skin abnormalities (lateralized sacral dimple) and controls showed cystic progression at 7 months. In 7 cases (25\%), the back pain progressed to sciatica. Other contemporary symptoms of back pain were: partial motor $(n=8)$ and/or sensitive $(n=3)$ deficit, bladder $(n=8)$ and bowel movement dysfunction $(n=3)$. The ependymoma was localized at the level of cauda equina in 15 patients, at the conus level in 4 or both at the same time in 9 patients. One presented associated bilateral vestibular schwannomas (underlying neurofibromatosis type 2) on cranial MRI. Metastatic seeds at the level of the inferior part of the lumbar cistern were present at diagnosis in 6 (21\%) cases: 4 were MPE's, 1 grade II and 1 grade III.

Preoperative spinal MRI was performed in all patients with additional cranial MRI in 5 patients for cranial extension research. All 28 patients underwent surgery with a laminotomy approach. Initial gross total resection (GTR) was obtained in 22 patients $(78,6 \%)$ and subtotal resection (STR) in 6 patients $(21,4 \%)$.

Histopathologic diagnosis was determined according the 2007 WHO classification by the local pathologist. No central review of histology was conducted since all participating institutions were ranked as reference 
centers in France. Fifteen were grade I (MPE), 11 grade II and 2 grades III. An initial GTR was obtained in 10 of 15 patients with grade I ependymoma, in 10 of 11 patients with grade II and in all patients $(n=2)$ with grade III. Initial STR was reported in 5 patients with grade I MPE and one with grade II. Two children of the MPE group who were in STR had an elective attempt of second look surgery resulting again in STR. Among 6 patients with seeding 4 patients had GTR (2 MPE, 1 gr II and 1 gr III) and 2 STR (both MPE) at initial surgery.

\section{Adjuvant Radiotherapy}

Six patients (21\%) received adjuvant RT after initial surgery: 4 in GTR (1 MPE, 2 Grade II and 1 Grade III) and 2 in STR (both MPE's) (Table2). The median dose used was of 46.6Gy with a range from 45 to $50.4 \mathrm{~Gy}$

Clinical course and status of remission

All patients were alive at the end of the study with a median follow-up period of 40 months ( 4 to 124 months).

Group with no relapse/progression

Eighteen patients (64\%) did not progress. The median follow-up was 23 months ( 2.3 to 127.5 months). There was a male predominance with 17 males (M) and 1 female (F): ratio M:F of 17:1. All patients had an initial GTR. Regarding histology, 7 were MPE's (46\% from all MPE's), 9 were grade II ( $81 \%$ from all grade II patients) and 2 were grade III (100\% of grade III). Four patients had received adjuvant RT (1 MPE, 2 grades II and 1 grade III) and 14 patients had not (6 MPE; 7 grades II, and 1 grade III).

\section{Group with relapse/progression (Table 3)}

Ten patients (37.5\%) relapsed or progressed. The median time from surgery to relapse was 24.9 months (range 11.2 to 70 months). The M:F ratio was 1:1: Five out of 6 (83.3\%) female versus 5 out of $22(22.7 \%)$ male presented a relapse/progression. Eight out of 10 patients were MPE ( 3 GTR and 5 SRT) and two were grade II (one GTR and one STR). 
Thus, altogether in the MPE group, 8/15 patients ultimately relapsed/progressed, 2 despite adjuvant RT: 3/9 GTR and 3/3 STR relapsed/progressed when no adjuvant radiation was delivered, whereas 0/1 GTR and 2/2 STR did so when adjuvant RT was delivered. In the grade II cohort, 1/8 patients with GTR and 1/1 with STR relapsed/progressed when no radiation was delivered, while 0/2 (Table 2) relapsed after receiving adjuvant RT for GTR.

The treatment of relapses included surgery with a laminotomy (6) or laminectomy (1): in 5 MPE's, 1 grade II and 1 grade III. In the latter, no tumoral tissue was found and the child remains in first remission. Two patients had further surgeries for progression of their residue: one with MPE with stable disease at follow-up after 2 more surgeries followed by salvage RT and one with grade Il ependymoma in remission at last follow-up after 3 more surgeries followed by salvage RT (Table 4).

Radiotherapy was given at time of relapse or progression in 5 MPE's and one grade II. One of the MPE patient received RT twice: at initial diagnosis and at relapse. Chemotherapy was administered only in 1 MPE patient with residue after first and second look surgeries, and received adjuvant RT. He received chemotherapy at time of further progression.

The follow-up of the group with relapse/progression $(n=10)$ shows complete remission in 3 patients $(30 \%)$, stable residual MRI images in 3 patients (33\%) and progression in 4 patients (44\%).

Survival analysis

With a median follow-up of 40 months ( $\min =2.3$; $\max =127.5)$, the 5 -year PFS is $51 \%($ IC95\% $=26.3 ; 71.2)$ and the overall survival (OS) is $100 \%$ (Figure 1). In univariate analysis, only the quality of the initial surgical removal has a significant influence on the PFS, the GTR being superior to STR $(p=0.0013)$. The details of the univariate analysis are shown in the table 5.

Complementary analysis was done on 4 subgroups according to the quality of the resection and adjuvant radiotherapy. Although the sample size is small, the subgroup analysis shows that RT may improve PFS in case of GTR $(p=0,006)$ (Figure 2). 


\section{Discussion}

Ependymoma is the most frequent spinal tumor in adults but it is rather uncommon in children. There appears to be a relationship between the age and location of ependymomas in children with a more frequent posterior fossa location in infants compared to spinal tropism in older children ${ }^{1}$. In recent decades, studies on the molecular signatures of ependymomas revealed distinct genetic expressions in the respect of age of the patients and the localization of these tumors. These differences may also explain the specifics of clinical evolution and response to treatment for each site ${ }^{4-6}$. The prognosis differs from MPE in children compared to adults because they may have initial spinal spread ${ }^{7}$ and may show a greater tendency to recur ${ }^{8-12}$. Moreover, the paediatric population appears to have a median recurrence time shorter than that of adults 12.

Relation between histology and prognosis is debated for grade II and III spinal ependymomas ${ }^{13}$. Recent studies on the molecular classification of ependymomas in children have shown common genetic alterations of the NF2 gene between WHO grade II and III spinal ependymomas ${ }^{6}$.

We observed a male predominance (78.6\%) already reported by McGuire et $\mathrm{al}^{1}$, but also à tendency for a higher recurrence rate for girls (66.7\%) but no statistical difference in PFS could be found. Only the GTR was statistically significantly associated with a better PFS. All other tested parameters (age, tumor location, histology, initial adjuvant RT) did not show a significant difference in PFS.

\section{Role of surgical treatment}

In spinal ependymoma, as for its intracranial counterpart, the quality of resection was identified as the main prognostic factor ${ }^{14-18}$. Several studies support that quality of surgery is associated with a good survival ${ }^{19,20}$. Our study also supports these findings, as PFS was clearly associated with GTR ( $p=0,0013)$. In this regard, the difficulty in managing spinal ependymomas is due to their location with high neurological risk associated to the surgery at the level of cauda equina, but also because of the initial loco-regional extension of the disease. The myxopapillary ependymomas are slow growing tumors with no significant trend towards histologic dedifferentiation. Surgery alone is the usual treatment and in more than $50 \%$ of the cases complete removal has been reported ${ }^{14,21}$. Long-term recurrence is not unusual, even after complete removal or with more 
aggressive treatment, requiring long follow-up ${ }^{14,22}$. Regarding the quality of the tumour removal for MPE's, some authors have found no differences in the PFS between GTR and STR ${ }^{22,23}$ and some studies have suggested the need for radiotherapy to improve local control even after GTR ${ }^{12,22}$.

Concerning grade II ependymomas, complete surgery is associated with good outcome ${ }^{24,25}$. The GTR rate varies between $50-100 \%$ in the literature ${ }^{26}$ and is $91 \%$ in our series. Gross total resection (GTR) seems to be associated with a favourable outcome with a PFS of 90 to $100 \%$ at 5 years ${ }^{27,28}$. Hence, a GTR is advocated even in the presence of functional risk as the OS was found significantly superior after GTR versus STR plus $\mathrm{RT}^{19}$. Although there is no strong evidence for initial adjuvant radiotherapy (RT) for completely removed grade II ependymomas, this hypothesis has been advocated following subtotal resection ${ }^{24,29}$.

For the grade III ependymomas the most reasonable strategy is surgery (GTR or STR) followed by radiotherapy ${ }^{24}$.

Other paediatric studies showed no difference of the PFS across histological grades (I, II and III) and that OS was better after GTR than STR regardless of tumor grade ${ }^{23,24}$. Likewise, our study found no statistical difference between the PFS related to the histological grade of the tumor.

With regard to the extension of the disease, the initial multifocal ependymoma is not unusual ${ }^{7}$. In our series, metastatic seeds at the lower part of the lumbar cistern were present at diagnosis in $6(21 \%)$ cases and not only in MPE. Therefore, even in cases with apparent complete removal, some residual synchronous lesions located on the roots may be left behind and may be targeted by complementary radiotherapy.

\section{Role of radiation therapy}

The role of the adjuvant radiotherapy in pediatric spinal ependymomas is still debated as relevant data are not available due to the rarity of these lesions in children. Some authors advocate the use of adjuvant radiotherapy only after STR in grade II-III ependymomas ${ }^{24,29}$ and others also in MPE's ${ }^{8,30}$. Nevertheless, multivariate analysis of radiotherapy in different grade ependymomas showed no difference for PFS ${ }^{23}$ or OS 31. 
Regarding complementary treatment for MPE, some series showed good results with STR and adjuvant RT 8,9 $^{8,9}$ or after GTR and RT ${ }^{32}$. In contrast, Bagley et al. ${ }^{33}$ found no significant role in the disease control for adjuvant RT in 14 pediatric patients with MPE.

Analysis of the PFS of our total population shows an improvement in outcome when the radiation was delivered to completely removed tumors $(p=0,006)$. Like other studies ${ }^{34}$, we find no advantage of use of RT in STR. Another recent study of child MPE's showed no benefit of RT on OS after GTR or STR but PFS analysis could not be done ${ }^{19}$.

However, for the grade 3 ependymomas radiotherapy is advocated as a complementary treatment in several studies ${ }^{18,24}$.

In the adults, the role of adjuvant radiation is also debated: some studies show a benefit of irradiation after STR only ${ }^{10,35-38}$, others recommend postoperative radiation even after $\mathrm{GTR}^{18,22}$

\section{Role of chemotherapy}

Chemotherapy for spinal ependymomas has been rarely used and only in refractory cases ${ }^{39}$. The use of high dose Tamoxifen has been reported in a child with recurrent spinal MPE after STR and radiotherapy, but results were only transient ${ }^{39}$. In our study, the combination of Cisplatin and Temozolomide in a child with progressive MPE after STR and RT did not stop the evolution of the disease. In a mixed series, Chamberlain et al. ${ }^{40}$ reported the prospective use of etoposide in 10 patients with recurrent intramedullary ependymoma with a stable or partial response following a single cycle of etoposide in $70 \%$ of cases for a period of 17 months. More recently, the bevacizumab has been showed to be effective in reducing the cystic forms of spinal ependymomas in NF2 patients but not the solid ones. For high grade ependymomas, chemotherapy may be used as an adjuvant treatment combined with radiotherapy ${ }^{41}$.

Considering new therapeutic alternatives for SpEp, a study identified the PDGFR alfa as a potential target. However, the use of PDGFR alfa inhibitor (Inatinib) did not show a consistent effect in the course of the disease ${ }^{42}$. 
Analysis of the outcome

In order to achieve GTR, there is a balance between the neurological risk associated to a radical surgery of ependymomas at the level of cauda equina and a potential increase in PFS. This is true especially for the MPE's as they show more tendency to recur in children ${ }^{43}$. Therefore, the neurological risk has to be considered especially at the level of infiltration around the nerve roots. Meanwhile, the risk in case of repeated surgery can be even higher as dissection is usually more difficult because of fibrotic attachments. Secondary radiotherapy, advocated in case of progression, is also at risk for delayed neurological impairment, secondary malignancies, growth and spinal deformity ${ }^{44}$.

The limitations of this study include the bias of a retrospective study with information's gathered from local data charts. We must also consider the bias of a collaborative multicentre study as the diagnosis, and the quality of the surgical and complementary treatment are heterogeneous.

\section{Conclusion}

Despite recent advances in the management of child CNS tumours, surgery remains the main core in the management of the MPE and grade II spinal ependymomas in children. Our data suggest that initial adjuvant radiotherapy may improve the PFS after GTR. Further studies with larger collaborative cohorts are necessary to confirm our findings of the need for more aggressive treatment in SpEp in children. 


\section{REFERENCES}

1. McGuire CS, Sainani KL, Fisher PG. Incidence patterns for ependymoma: a Surveillance, Epidemiology, and End Results study. J Neurosurg. 2009;110(4):725-729. doi:10.3171/2008.9.JNS08117.

2. Schellinger KA, Propp JM, Villano JL, McCarthy BJ. Descriptive epidemiology of primary spinal cord tumors. J Neurooncol. 2008;87(2):173-179. doi:10.1007/s11060-007-9507-z.

3. Louis DN, Ohgaki H, Wiestler OD, et al. The 2007 WHO classification of tumours of the central nervous system. Acta Neuropathol. 2007;114(2):97-109. doi:10.1007/s00401-0070243-4.

4. Korshunov A, Neben K, Wrobel G, et al. Gene expression patterns in ependymomas correlate with tumor location, grade, and patient age. Am J Pathol. 2003;163(5):1721-1727. doi:10.1016/S0002-9440(10)63530-4.

5. Palm T, Figarella-Branger D, Chapon F, et al. Expression profiling of ependymomas unravels localization and tumor grade-specific tumorigenesis. Cancer. 2009;115(17):39553968. doi:10.1002/cncr.24476.

6. Pajtler KW, Witt H, Sill M, et al. Molecular Classification of Ependymal Tumors across All CNS Compartments, Histopathological Grades, and Age Groups. Cancer Cell. 2015;27(5):728-743. doi:10.1016/j.ccell.2015.04.002.

7. Landriel F, Tedesco N, Vecchi E, Ajler P, Bendersky D. Multicentric extramedullary myxopapillary ependymomas: Two case reports and literature review. Surg Neurol Int. 2012;3(1):102. doi:10.4103/2152-7806.100859.

8. Merchant TE, Kiehna EN, Thompson SJ, Heideman R, Sanford RA, Kun LE. Pediatric lowgrade and ependymal spinal cord tumors. Pediatr Neurosurg. 2000;32(1):30-36. doi:28894.

9. Fassett DR, Pingree J, Kestle JRW. The high incidence of tumor dissemination in myxopapillary ependymoma in pediatric patients. Report of five cases and review of the literature. J Neurosurg. 2005;102(Pediatrics 1):59-64. doi:10.3171/ped.2005.102.1.0059. 
10. Lin Y-H, Huang C-I, Wong T-T, et al. Treatment of spinal cord ependymomas by surgery with or without postoperative radiotherapy. J Neurooncol. 2005;71(2):205-210. doi:10.1007/s11060-004-1386-y.

11. Pica A, Miller R, Villa S, et al. Ep RCN Myxopapillary: The results of surgery, with or without radiotherapy, for primary spinal myxopapillary ependymoma: a retrospective study from the rare cancer network. IJROBP. 2009;74(4):1114-1120. doi:10.1016/j.ijrobp.2008.09.034.

12. Feldman WB, Clark AJ, Safaee M, Ames CP, Parsa AT. Tumor control after surgery for spinal myxopapillary ependymomas: distinct outcomes in adults versus children: a systematic review. J Neurosurg Spine. 2013;19(4):471-476. doi:10.3171/2013.6.SPINE12927.

13. Louis DN, Perry A, Reifenberger G, et al. The 2016 World Health Organization Classification of Tumors of the Central Nervous System: a summary. Acta Neuropathol. 2016;131(6):803-820. doi:10.1007/s00401-016-1545-1.

14. Sonneland PR, Scheithauer BW, Onofrio BM. Myxopapillary ependymoma. A clinicopathologic and immunocytochemical study of 77 cases. Cancer. 1985;56(4):883-893.

15. Pollack IF, Gerszten PC, Martinez a. J, et al. Intracranial ependymomas of childhood: Longterm outcome and prognostic factors. Neurosurgery. 1995;37(4):655-667. doi:10.1227/00006123-199510000-00008.

16. Chang UK, Choe WJ, Chung SK, Chung CK, Kim HJ. Surgical outcome and prognostic factors of spinal intramedullary ependymomas in adults. J Neurooncol. 2002;57(2):133-139.

17. Merchant TE. Three-dimensional conformal radiation therapy for ependymoma. Childs Nerv Syst. 2009;25(10):1261-1268. doi:10.1007/s00381-009-0892-9.

18. Boström A, von Lehe M, Hartmann W, et al. Surgery for Spinal Cord Ependymomas. Neurosurgery. 2011;68(2):302-309. doi:10.1227/NEU.0b013e3182004c1e.

19. Lucchesi KM, Grant R, Kahle KT, Marks AM, DiLuna ML. Primary spinal myxopapillary 
ependymoma in the pediatric population: a study from the Surveillance, Epidemiology, and End Results (SEER) database. J Neurooncol. 2016;130(1):133-140. doi:10.1007/s11060016-2218-6.

20. Benesch M, Weber-Mzell D, Gerber NU, et al. Ependymoma of the spinal cord in children and adolescents: a retrospective series from the HIT database. J Neurosurg Pediatr. 2010;6(2):137-144. doi:10.3171/2010.5.PEDS09553.

21. Gagliardi FM, Cervoni L, Domenicucci M, Celli P, Salvati M. Ependymomas of the filum terminale in childhood: report of four cases and review of the literature. Childs Nerv Syst. 1993;9(1):3-6.

22. Akyurek S, Chang EL, Yu T-K, et al. Spinal myxopapillary ependymoma outcomes in patients treated with surgery and radiotherapy at M.D. Anderson Cancer Center. $J$ Neurooncol. 2006;80(2):177-183. doi:10.1007/s11060-006-9169-2.

23. Safaee M, Oh MC, Mummaneni P V, et al. Surgical outcomes in spinal cord ependymomas and the importance of extent of resection in children and young adults. J Neurosurg Pediatr. 2014;13(4):393-399. doi:10.3171/2013.12.PEDS13383.

24. Benesch M, Frappaz D, Massimino M. Spinal cord ependymomas in children and adolescents. Child's Nerv Syst. 2012;28(12):2017-2028. doi:10.1007/s00381-012-1908-4.

25. Tarapore PE, Modera P, Naujokas A, et al. Pathology of spinal ependymomas: An institutional experience over 25 years in 134 patients. Neurosurgery. 2013;73(2):247-255. doi:10.1227/01.neu.0000430764.02973.78.

26. Lin Y, Jea A, Melkonian SC, Lam S. Treatment of pediatric Grade II spinal ependymomas: a population-based study. J Neurosurg Pediatr. 2015;15(3):243-249. doi:10.3171/2014.9.PEDS1473.

27. Lonjon M, Goh KY, Epstein FJ. Intramedullary spinal cord ependymomas in children: treatment, results and follow-up. Pediatr Neurosurg. 1998;29(4):178-183. doi:10.1159/000028718. 
28. Kukreja S, Ambekar S, Sin AH, Nanda A. Cumulative survival analysis of patients with spinal myxopapillary ependymomas in the first 2 decades of life. J Neurosurg Pediatr. 2014;13(4):400-407. doi:10.3171/2014.1.PEDS13532.

29. Lin Y, Smith Z a., Wong AP, Melkonian S, Harris D a., Lam S. Predictors of survival in patients with spinal ependymoma. Neurol Res. 2015. doi:10.1179/1743132815Y.0000000041.

30. Al-halabi H, Montes L, Atkinson J, Farmer J, Freeman CR. Adjuvant Radiotherapy in the Treatment of Pediatric Myxopapillary Ependymomas. 2010;(May):639-643. doi:10.1002/pbc.

31. Pędziwiatr K, Skowrońska-Gardas A, Chojnacka M. Spinal cord ependymoma in children Results of postoperative radiotherapy. Radiother Oncol. 2013;106(2):181-185. doi:10.1016/j.radonc.2013.02.007.

32. Ross DA, McKeever PE, Sandler HM, Muraszko KM. Myxopapillary ependymoma. Results of nucleolar organizing region staining. Cancer. 1993;71(10):3114-3118. doi:10.1002/10970142(19930515)71:10<3114::AID-CNCR2820711036>3.0.CO;2-Q.

33. Bagley CA, Kothbauer KF, Wilson S, Bookland MJ, Epstein FJ, Jallo GI. Resection of myxopapillary ependymomas in children. J Neurosurg. 2007;106(4 Suppl):261-267. doi:10.3171/ped.2007.106.4.261.

34. Constantini S, Miller DC, Allen JC, Rorke LB, Freed D, Epstein FJ. Radical excision of intramedullary spinal cord tumors: surgical morbidity and long-term follow-up evaluation in 164 children and young adults. J Neurosurg. 2000;93(2 Suppl):183-193. doi:10.3171/spi.2000.93.2.0183.

35. Marco A Di, Griso C, Pradella R, Campostrini F, Garusi GF. Postoperative management of primary spinal cord ependymomas. Acta Oncol (Madr). 1988;27(4):371-375. doi:10.3109/02841868809093557.

36. Lee TT, Gromelski EB, Green BA. Surgical treatment of spinal ependymoma and post- 
operative radiotherapy. Acta Neurochir (Wien). 1998;140(4):309-313.

doi:10.1007/s007010050103.

37. Wahab SH, Simpson JR, Michalski JM, Mansur DB. Long term outcome with post-operative radiation therapy for spinal canal ependymoma. J Neurooncol. 2007;83(1):85-89. doi:10.1007/s11060-006-9310-2.

38. Whitaker SJ, Bessell EM, Ashley SE, Bloom HJ, Bell BA, Brada M. Postoperative radiotherapy in the management of spinal cord ependymoma. J Neurosurg. 1991;74(5):720728. doi:10.3171/jns.1991.74.5.0720.

39. Madden JR, Fenton LZ, Weil M, Winston KR, Partington M, Foreman NK. Experience with tamoxifen/etoposide in the treatment of a child with myxopapillary ependymoma. Med Pediatr Oncol. 2001;37(1):67-69. doi:10.1002/mpo.1168.

40. Chamberlain MC. Salvage chemotherapy for recurrent spinal cord ependymona. Cancer. 2002;95(5):997-1002. doi:10.1002/cncr.10826.

41. Aghakhani N, Messerer M, David P, Herbrecht A, Parker F. [Intramedullary ependymomas: A French retrospective multicenter study of 221 cases]. Neurochirurgie. February 2017. doi:10.1016/j.neuchi.2016.07.002.

42. Fakhrai N, Neophytou P, Dieckmann K, et al. Recurrent spinal ependymoma showing partial remission under Imatimib. Acta Neurochir (Wien). 2004;146(11):1255-1258. doi:10.1007/s00701-004-0374-5.

43. Bagley CA, Wilson S, Kothbauer KF, Bookland MJ, Epstein F, Jallo GI. Long term outcomes following surgical resection of myxopapillary ependymomas. Neurosurg Rev. 2009;32(3):321-334. doi:10.1007/s10143-009-0190-8.

44. O’Sullivan C, Jenkin D, Doherty MA, Hoffman HJ GM. Spinal cord tumors in children: long-term results of combined surgical and radiation treatment. J Neurosurg. 1994;81:507512. 


\section{Figures legend:}

Figure1. Evolution of the progression free survival.

Figure 2. Analysis of progression free survival for 4 groups depending on the quality of resection (GTR/STR) and adjuvant RT (with RT/ without RT). 


\section{Product-Limit Survival Estimates}

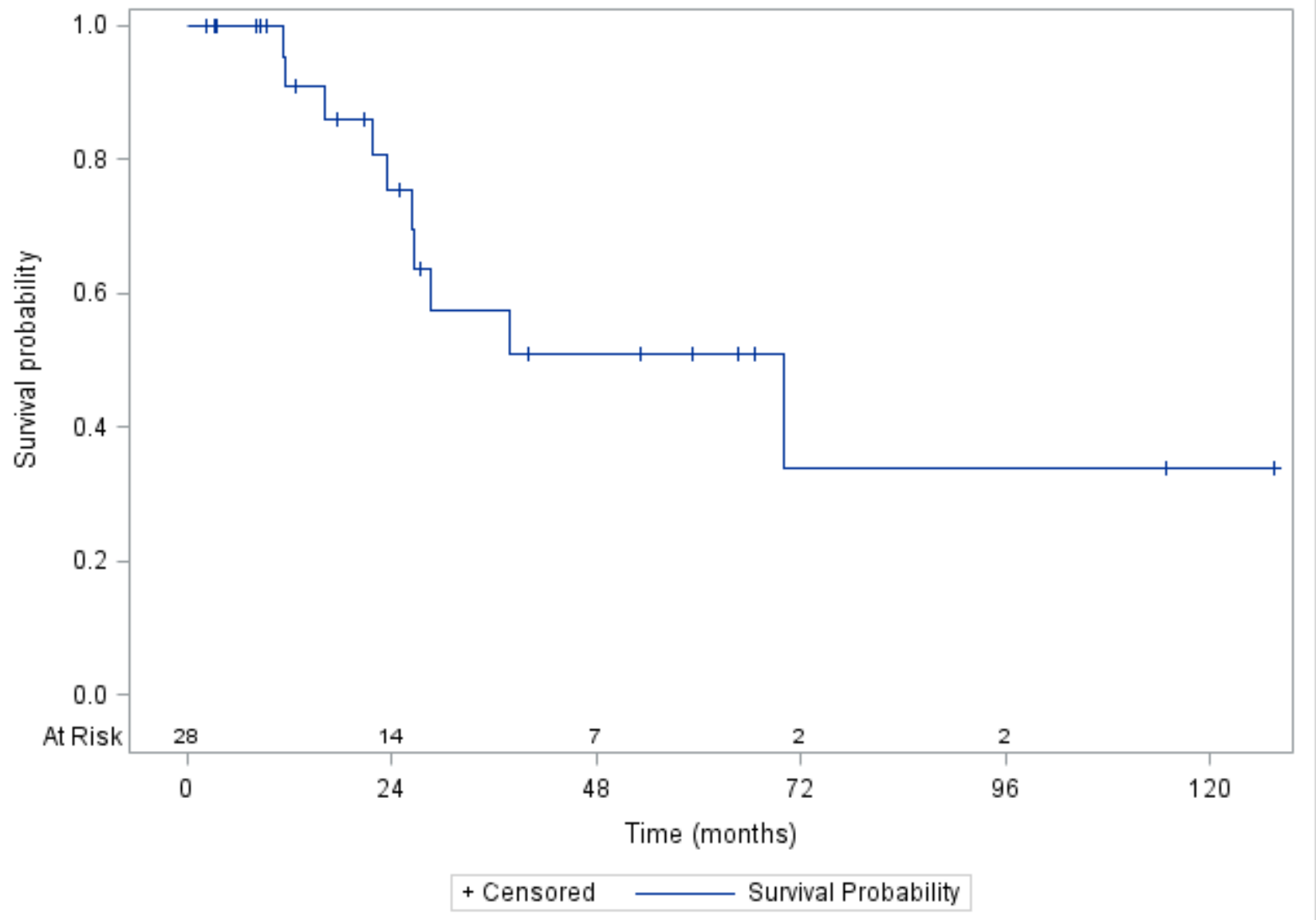




\section{Product-Limit Survival Estimates}

With Number of Subjects at Risk

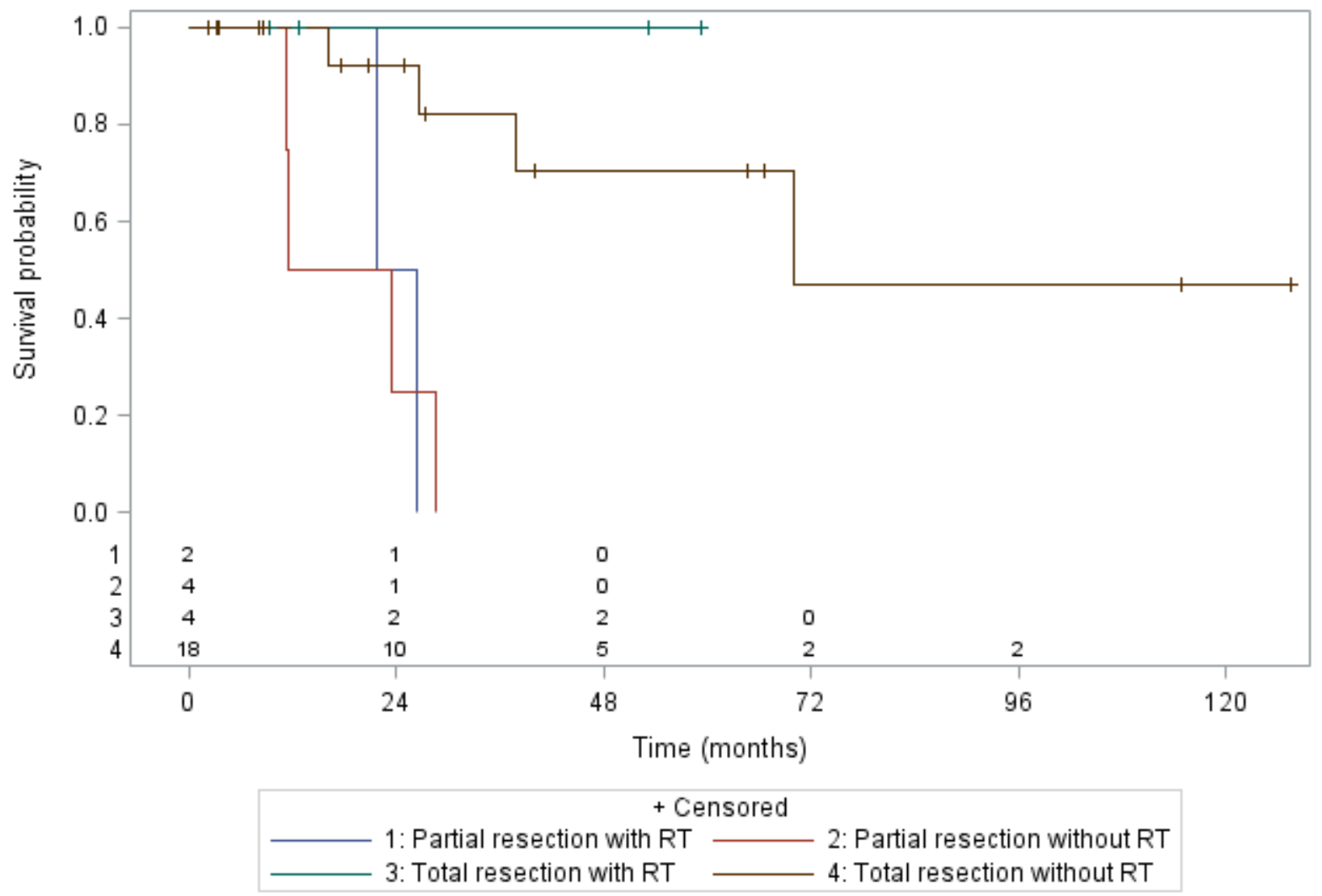




\begin{tabular}{|c|c|}
\hline Patients characteristics & Number (\%) \\
\hline Total & $28(100)$ \\
\hline $\begin{array}{l}\text { Age at surgery (yrs.) } \\
\text { Mean (Std.) } \\
\text { Median [min-max] }\end{array}$ & $\begin{array}{l}12.5(3.6) \\
13.67[0.71-17.64]\end{array}$ \\
\hline $\begin{array}{ll}\text { Sex } & \\
& \text { Male } \\
& \text { Female } \\
\end{array}$ & $\begin{array}{l}22(78.6) \\
6(21.4)\end{array}$ \\
\hline $\begin{array}{l}\text { Level } \\
\text { Cauda equina } \\
\text { Conus } \\
\text { Cauda equina }+ \text { conus }\end{array}$ & $\begin{array}{l}15(53.6) \\
4(14.3) \\
9(32.1) \\
\end{array}$ \\
\hline Metastatic seeds (lumbar cistern) & $6(21)$ \\
\hline $\begin{array}{l}\text { Removal } \\
\text { GTR } \\
\text { STR }\end{array}$ & $\begin{array}{l}22(78.6) \\
6(21.4)\end{array}$ \\
\hline Adjuvant RT & $6(214 \%)$ \\
\hline $\begin{array}{cc}\text { Grade } & \\
& \text { I } \\
\text { II } \\
\text { III }\end{array}$ & $\begin{array}{l}15(53.6) \\
11(39.3) \\
2(7.1) \\
\end{array}$ \\
\hline $\begin{array}{l}\text { No recurrence } \\
\text { Recurrence }\end{array}$ & $\begin{array}{l}18(64.2) \\
10(35.7) \\
\end{array}$ \\
\hline $\begin{array}{l}\text { Current status } \\
\text { First complete remission } \\
\text { Further complete remission } \\
\text { Stable } \\
\text { Progression }\end{array}$ & $\begin{array}{l}18(64.2) \\
3(10.7) \\
3(10.7) \\
4(14.3)\end{array}$ \\
\hline
\end{tabular}

Table. 1. Patients characteristics. GTR: gross total removal, STR: subtotal removal, RT: radiotherapy. First complete remission=remission obtained after 1 surgery +/- complementary treatment. Further complete remission=remission obtained after more than one surgery +/- complementary treatment. 


\begin{tabular}{|c|c|c|c|c|c|}
\hline $\begin{array}{c}\text { Case } \\
\text { no }\end{array}$ & Grade & $\begin{array}{c}\text { Initial surgery } \\
\text { GTR/STR }\end{array}$ & $\begin{array}{c}\text { Adjuvant RT } \\
(\mathrm{Y} / \mathrm{N})\end{array}$ & $\begin{array}{c}\text { Salvage RT } \\
(\mathrm{Y} / \mathrm{N})\end{array}$ & $\begin{array}{c}\text { Clinical } \\
\text { status }\end{array}$ \\
\hline 16 & $\mathrm{I}$ & STR & $\mathrm{Y}$ & $\mathrm{N}$ & $\mathrm{PD}$ \\
\hline 17 & $\mathrm{I}$ & STR & $\mathrm{Y}$ & $\mathrm{Y}$ & $\mathrm{SD}$ \\
\hline 26 & $\mathrm{I}$ & GTR & $\mathrm{Y}$ & $\mathrm{N}$ & $\mathrm{CR}$ \\
\hline 5 & $\mathrm{II}$ & GTR & $\mathrm{Y}$ & $\mathrm{N}$ & $\mathrm{CR}$ \\
\hline 25 & II & GTR & $\mathrm{Y}$ & $\mathrm{N}$ & $\mathrm{CR}$ \\
\hline 19 & III & GTR & $\mathrm{Y}$ & $\mathrm{N}$ & $\mathrm{CR}$ \\
\hline
\end{tabular}

Table 2. List of patients who received radiotherapy in adjuvant setting. $\mathrm{PD}=$ progressive disease, $\mathrm{SD}=$ stable disease, $\mathrm{CR}=$ complete remission 


\begin{tabular}{|l|l|l|l|l|l|l|l|}
\hline No & Grade & $\begin{array}{l}\text { Initial } \\
\text { Surgery } \\
\text { GTR/STR }\end{array}$ & $\begin{array}{l}\text { Adjuvant RT } \\
\text { (Y/N) }\end{array}$ & $\begin{array}{l}\text { Relapse (1) } \\
\text { Progression } \\
(2)\end{array}$ & $\begin{array}{l}\text { Treatment at } \\
\text { recurrence or } \\
\text { progression }\end{array}$ & $\begin{array}{l}\text { Salvage RT } \\
\text { (Y/N) }\end{array}$ & $\begin{array}{l}\text { Clinical } \\
\text { status }\end{array}$ \\
\hline 21 & I & GTR & N & 1 & Surg & N & CR \\
\hline 3 & I & GTR & N & 1 & Surg & Y & PD \\
\hline 18 & I & GTR & N & 1 & Surg & Y & SD \\
\hline 1 & I & STR & N & 2 & Surg & Y & PD \\
\hline 16 & I & STR & Y & 2 & CT & N & PD \\
\hline 17 & I & STR & Y & 2 & RT & Y & SD \\
\hline 14 & I & STR & N & 2 & RT & Y & CR \\
\hline 15 & I & STR & N & 2 & Surg & Y & SD \\
\hline 7 & II & GTR & N & 1 & 0 & N & PD \\
\hline 12 & II & STR & N & 2 & Surg & Y & CR \\
\hline
\end{tabular}

Table 3. Patients with recurrence or progression. Surg=surgery, RT=radiotherapy, $C T=$ chemotherapy, $0=$ no treatment, $\mathrm{CR}=$ complete remission, $\mathrm{PD}=$ progressive disease, $\mathrm{SD}=$ stable disease. 


\begin{tabular}{|c|c|c|c|c|c|c|c|c|}
\hline \multirow[t]{2}{*}{ No } & \multirow[t]{2}{*}{ Grade } & \multirow{2}{*}{$\begin{array}{c}\text { Initial } \\
\text { surgery } \\
\text { GTR/STR }\end{array}$} & \multirow{2}{*}{$\begin{array}{l}\text { Adjuvant } \\
\text { RT }(\mathrm{Y} / \mathrm{N})\end{array}$} & Relapse (1) & \multirow{2}{*}{$\begin{array}{l}\text { Further } \\
\text { Surgery } \\
x 1,2,3\end{array}$} & \multirow{2}{*}{$\begin{array}{l}\text { Quality of } \\
\text { further } \\
\text { resection(s) }\end{array}$} & \multirow{2}{*}{$\begin{array}{l}\text { Salvage RT } \\
(\mathrm{Y} / \mathrm{N})\end{array}$} & \multirow{2}{*}{$\begin{array}{c}\text { Last know } \\
\text { Clinical status }\end{array}$} \\
\hline & & & & $\begin{array}{c}\text { Progression } \\
\text { (2) }\end{array}$ & & & & \\
\hline 21 & 1 & GTR & $\mathrm{N}$ & 1 & 1 & GTR & $\mathrm{N}$ & CR2 \\
\hline 3 & 1 & GTR & $\mathrm{N}$ & 1 & 1 & GTR & $\mathrm{Y}$ & PD \\
\hline 18 & I & GTR & $\mathrm{N}$ & 1 & 1 & GTR & $Y$ & SD \\
\hline 1 & I & STR & $N$ & 2 & 1 & STR & $\mathrm{Y}$ & PD \\
\hline 15 & I & STR & $\mathrm{N}$ & 2 & 2 & STR & $Y$ & SD \\
\hline 12 & II & STR & $\mathrm{N}$ & 2 & 3 & GTR & $Y$ & CR2 \\
\hline 10 & III & GTR & $N$ & $\begin{array}{l}1 \text { (negative } \\
\text { histology) }\end{array}$ & 1 & $\begin{array}{c}\text { GTR } \\
\text { (negative } \\
\text { histology) }\end{array}$ & $N$ & CR \\
\hline
\end{tabular}

Table 4. List of patients with further surgeries. CR2=secondary complete remission, $P D=$ progressive disease,

$\mathrm{SD}=$ stable disease. 


\begin{tabular}{|c|c|c|c|}
\hline Variables & Events no./Patients no. & HR (IC95\%) & p-value \\
\hline $\begin{array}{l}\text { Gender } \\
\qquad \begin{array}{l}\text { Male (Ref) } \\
\text { Female }\end{array} \\
\end{array}$ & $\begin{array}{l}5 / 22 \\
5 / 6 \\
\end{array}$ & $\begin{array}{c}1 \\
2.755[0.80-9.55]\end{array}$ & 0.1102 \\
\hline $\begin{array}{l}\text { Age at surgery } \\
\quad \geq 13.5 \text { yrs. (Ref) } \\
<13.5 \text { yrs. }\end{array}$ & $\begin{array}{l}5 / 16 \\
5 / 12 \\
\end{array}$ & $\begin{array}{c}1 \\
1.422[0.41-4.95]\end{array}$ & 0.5801 \\
\hline $\begin{array}{l}\text { Level } \\
\text { Cauda equina only } \\
\text { Conus } \pm \text { cauda equina }\end{array}$ & $\begin{array}{l}7 / 15 \\
3 / 13\end{array}$ & $\begin{array}{c}1 \\
2.417[0.62-9.44]\end{array}$ & 0.2043 \\
\hline $\begin{array}{l}\text { Grade } \\
\\
\text { Grade I (Ref) } \\
\text { Grade II }\end{array}$ & $\begin{array}{l}8 / 15 \\
2 / 11\end{array}$ & $\begin{array}{c}1 \\
0.253[0.05-1.21]\end{array}$ & 0.2257 \\
\hline $\begin{array}{c}\text { Quality of surgical removal } \\
\text { GRT (Ref) } \\
\text { STR } \\
\end{array}$ & $\begin{array}{l}4 / 22 \\
6 / 6 \\
\end{array}$ & $14.684[2.85-75.76]$ & 0.0013 \\
\hline $\begin{array}{c}\text { Adjuvant radiotherapy (ART) } \\
\text { No (Ref) } \\
\text { Yes }\end{array}$ & $\begin{array}{l}8 / 22 \\
2 / 6\end{array}$ & $\begin{array}{c}1 \\
1.036[0.22-5.00]\end{array}$ & 0.9644 \\
\hline
\end{tabular}

Table. 5. Results of the univariate analysis for gender, age, level of the lesion, histological grade, quality of the initial surgery and adjuvant radiotherapy. 